\title{
Launching Pastoralism as an open access journal with SpringerOpen
}

\author{
Carol Kerven ${ }^{*}$ and Roy Behnke
}

* Correspondence: carol_kerven@msn.com Odessa Centre Ltd, Warwickshire, UK
From now on, Pastoralism: Research, Policy and Practice will be published online by SpringerOpen, as an open access journal (Figure 1).

The first two issues (Volume 1, 2010) were published by Practical Action Publishers (UK).

\section{What is open access?}

Open access (OA) makes articles published in a journal freely available online. OA journals operate in the same way as traditional journals, including stringent and thorough peer-review. The only difference is the business model: traditional journal articles are available through subscription, with no fee levied for publication. Open access journal articles are available freely, with a fee levied upon publication. Once an OA article is published it can be redistributed and reused as long as the article is correctly attributed.

To enable the journal to make part of its content open access, Pastoralism has obtained sponsorship for discretionary waivers to article processing charges (APC) for a number of manuscripts accepted after peer review. Other accepted manuscripts may have an APC levied.

Due to Springer's cooperation with BioMed Central, SpringerOpen journals are included in BioMed Central's Membership Program. If your institution is a Member the cost for the APC is covered in full or in part by the Membership.

The journal is sponsored by:

- International Institute for Environment and Development (IIED)

http://www.iied.org/climate-change/key-issues/drylands/pastoralism-journalresearch-policy-and-practice

- International Union for the Conservation of Nature (IUCN) World Initiative for Sustainable Pastoralism (WISP),

http://www.iucn.org/wisp/pastoralism__research_policy_practice/

- Odessa Centre UK.

http://www.odessacentre.co.uk/

The penetration of this journal into remote district offices, government research establishments and NGOs with limited internet access, will be ensured by a limited distribution of printed copies. 


\section{SpringerOpen ${ }^{\circ}$}

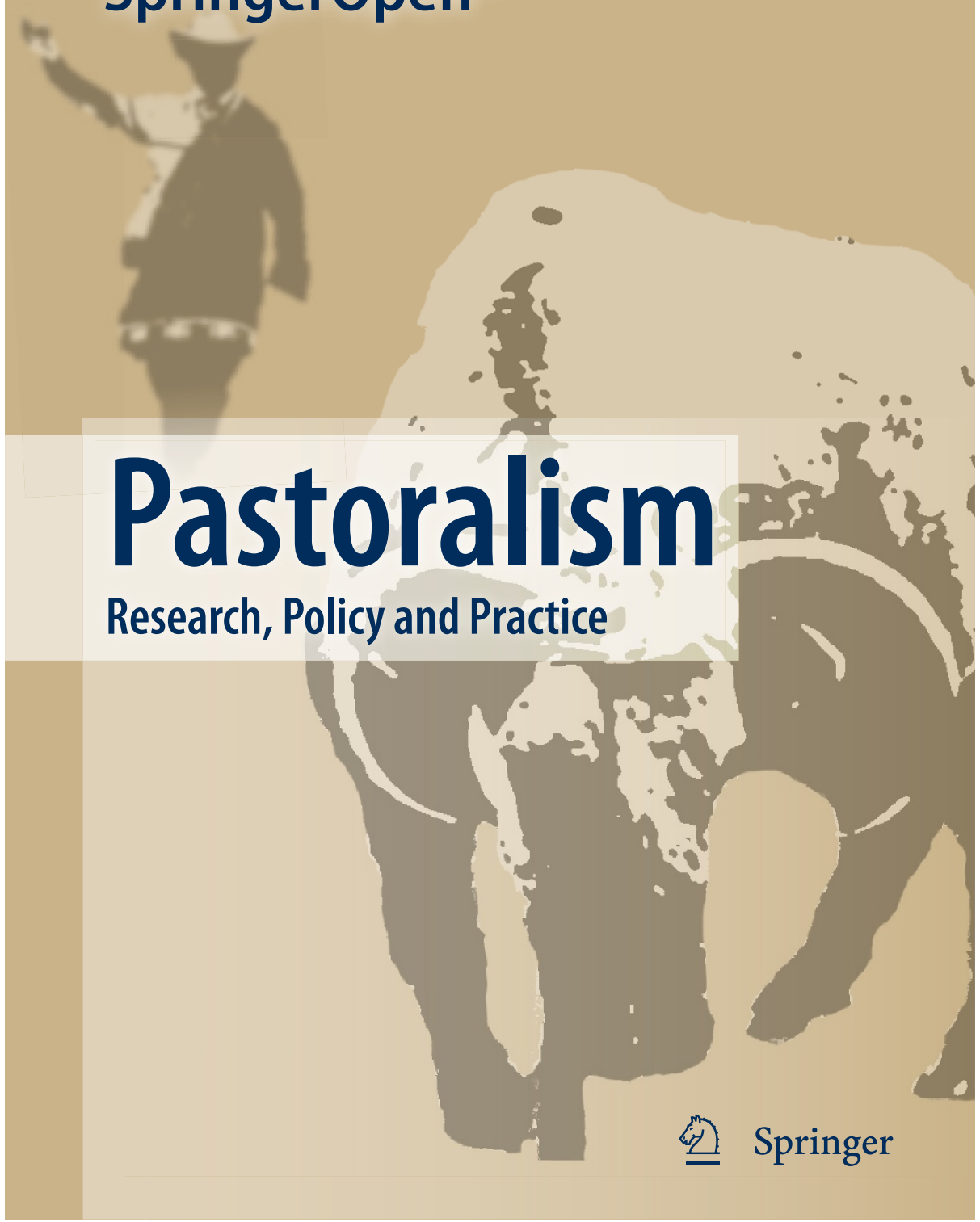

Figure 1 Cover for the SpringerOpen Journal.

In Volume 1 published by Practical Action Publishing (UK) Issue 1 was on "Mobile Pastoralism in the Industrial World", with case studies from western USA, Australia, Romania, Spain, France and Brazil, as well as two book reviews. Issue 2 contained articles focussed on southern Africa, Siberia, western China, Tajikistan, Ethiopia and Patagonia. This issue also contained a note on research in progress on the Tibetan plateau and two book reviews.

\section{Who will be the Journal's contributors?}

Pastoralism, incorporating ranching, refers to extensive livestock production mainly on natural pastures and is a global phenomenon. From the semi-arid tropics to the Arctic, 
it is practiced in environments as varied as deserts and savannahs, marshes, high meadows, plains and tundra. By sourcing material worldwide, Pastoralism promotes the comparative analysis of this varied and widespread production system throughout the world.

The journal publishes research and field experience that influences policy and practice, to improve the welfare of pastoral people, better conserve the environments in which they live, and contribute to broad economic development. Pastoralism is committed to publishing material not just by researchers but also by administrators and field workers who would not normally contribute to a scientific journal.

\section{Who will be the Journal's readers?}

After the first issue of the Journal was published in September 2009, our sponsors IIED and IUCN WISP placed announcements in their emailed bulletins and websites, and flyers were distributed by Odessa Centre. A number of people registered to receive information about the journal, on the WISP website, or by contacting IIED or the editors at Odessa Centre.

There are several remarkable features shown by the geographical locations of those who had registered their interest in the Journal by late 2010 .

Africa 50\%

Europe $23 \%$

Asia and Australia 11\%

North America 10\%

Latin America 6\%

Half the registered readers were based in Africa, and nearly one third (29\%) of all readers were based in only two countries: Kenya and Ethiopia.

There is a discrepancy between the geographical distribution of those who initially expressed interest in the Journal and the actual dispersion of pastoralists in the developing world. An analysis of a report by the International Livestock Research Institute ILRI (Thornton et al. 2002), in Table 1 shows the regional distribution of people defined by ILRI as livestock-dependent and rangeland-based in parts of countries which are arid/semi-arid, humid/subhumid or temperate/tropical highlands. Of the

Table 1 Regional breakdown of pastoralist populations in developing world

\begin{tabular}{|c|c|c|c|}
\hline REGION & & Millions & $\%$ \\
\hline West Asia, excluding N. Africa & & 31.1 & 17 \\
\hline East Asia, inc. China & & 21.6 & 12 \\
\hline South Asia, inc. Pakistan and India & & 19.3 & 11 \\
\hline Ex USSR & & 8.2 & 5 \\
\hline \multirow[t]{2}{*}{ South East Asia } & & 1.4 & 1 \\
\hline & sub-total & 81.6 & 46 \\
\hline Sub-Saharan Africa & & 61.9 & 34.3 \\
\hline \multirow[t]{2}{*}{ North Africa } & & 5.1 & 2.8 \\
\hline & sub-total & 67 & 37 \\
\hline \multirow[t]{2}{*}{ Central and South America } & & 32.1 & 18 \\
\hline & TOTAL & 180.7 & $100 \%$ \\
\hline
\end{tabular}

Source: Thornton et al. 2002. 
total 39 of these countries, 18 (46\%) have no representatives among the Journal's registered readers. The countries with the largest pastoral populations, i.e. China, Pakistan, Brazil, Yemen, Sudan, Iran, Somalia etc. are presently very poorly represented among the Journal readers. ILRI's compilation of livestock data in 2002 did not include "northern" or developed rich countries of western Europe, Russia, North America, Australia, Japan etc. Classifications change as countries grow richer, and the BRIC countries of Brazil, Russia, India and China would not now be classified as developing, but Brazil, India and China are included in the ILRI 2002 data base (Thornton et al. 2002), while Russia was not.

The majority of pastoralists (45\%) are found in Asia (including the Middle East), specifically in China, Pakistan, Iran, Yemen, Saudi Arabia, Afghanistan and Kazakhstan, as well as other countries. However, only $11 \%$ of journal readers are so far based in Asia, and a negligible amount from Latin America. It is therefore clear where we need to recruit new readers and contributors. With the transition to SpringerOpen, those who wish to read the journal no longer need to subscribe, pay or sign up. Readers can set up email alerts on SpringerOpen to be informed when a new article is published online in Pastoralism journal. This is an important new channel for widening the representativeness of our Journal.

There are also pastoralist populations in developed countries, and one third of our currently-registered readers are based in Europe, USA and Australia. In recognition of this, the editors have solicited a series of research and policy articles on pastoralists in former socialist eastern and southeastern Europe, which will appear soon in the Journal.

\section{Research articles now published on line}

Here we briefly introduce the first group of research papers launched on the SpringerOpen online website. There are five papers all set in Asia, spanning not only very dissimilar environments and peoples - mountains and deserts of Pakistan, tropical plains of India, cold desert Tibetan plateau - but including a paper on the pre-history of pastoralism in the Eurasian steppes. This assembly of papers well represents the broad concerns of the Journal, with contributions from practitioners as well as academics, and covering diverse disciplines from animal science, archaeology, forestry, geography, grassland science, socio-economics, and veterinary science.

Several general points arise from these articles. Two of the papers (Kumar et al. and Ptackova) discuss the consequences of sedentarisation - settling down of previously mobile pastoralists. In a case from the southern India semi-arid grasslands, over a century and half former mobile pastoralists acquired secure land rights and have spontaneously developed a form of rotational grazing, using live fences and supplementary feeding, which results in a stable form of settled pastoralism. The Tibetan nomads of western China are only now being settled through government-sponsored programmes, and are losing their communal grazing land rights while gaining modern housing and social benefits. The consequences for their pastoralist production and social systems are as yet barely known.

The paper by ur-Rahim et al. about a region in the Hindu Kush mountains of Pakistan draws out the entangled effects of government forestry interventions and central government land tenure reforms on political control, inter-ethnic relations and 
access to fodder trees by multiple different user groups. The introduction of exotic tree species and transference of property usage rights from mobile pastoralists to sedentary landlords has left mobile pastoralists the losers. The authors offer practical recommendations for re-introducing nutritionally-valuable indigenous fodder tree species.

In the hot dry plains of Pakistan, several pastoralist groups raise two breeds of camels, each with distinctive physiological and economically important attributes - for racing, milking, meat and transport. The paper by Kakar et al. provides a description of these two breeds, and argues that the breeds are under threat as their pastoralist owners are losing access to grazing lands due to encroachment of irrigated cotton and cereal farming by wealthy outsiders to this desert region. The authors end by proposing development measures which could uphold the role of the camel breeds and support the pastoralist societies.

Pastoralism has deep roots into pre-history, which can only be understood through archeological investigations, as shown in the paper by Bendrey. In one of the geographical origins of pastoralism - the Eurasian steppe - there is great variability in the environmental and biological factors which can affect the predominance of the main domestic livestock species of cattle, sheep/goats and horses. The author concludes that "comparison of the later prehistoric animal bone assemblages and the modern and historic livestock herd compositions... show a number of consistencies indicating the strong influence of the environment on the pastoral economies practiced across the Eurasian steppe".

In this collection of research articles, while one paper (Bendrey) informs us about the origins of pastoralism in Asia many millennia ago, another (Ptackova) tells us about the probable extinction of at least one pastoral mode - Tibetan nomads in China which is happening right now.

Inam-ur-Rahim, Daniel Maselli, Henri Rueff, Urs Wiesmann, Indigenous fodder trees can increase grazing accessibility for landless and mobile pastoralists in northern Pakistan

Abdul Raziq Kakar, Kerstin de Verdier and Muhammad Younas, Rapid change of strategy is necessary for development of dromedary camel pastoralism in the Cholistan desert of Pakistan

Jarmila Ptackova, Sedentarisation of Tibetan nomads in China: Implementation of the Nomadic settlement project in the Tibetan Amdo area; Qinghai and Sichuan Provinces

Robin Bendrey, Some like it hot: environmental determinism and the pastoral economies of the later prehistoric Eurasian steppe

Anil Kumar, S. Natarajan, N.B. Biradar and B. K. Trivedi, Evolution of sedentary pastoralism in south India: case study of the Kangayam grassland

Received: 8 April 2011 Accepted: 9 May 2011 Published: 9 May 2011

Reference

Thornton, PK, RL Kruska, N Henninger, PM Kristjanson, RS Reid, E Atieno, AN Odero, and T Ndegwa. 2002. Mapping Poverty and Livestock in the Developing World. Nairobi: International Livestock Research Institute.

doi:10.1186/2041-7136-1-1

Cite this article as: Kerven and Behnke: Launching Pastoralism as an open access journal with SpringerOpen.

Pastoralism: Research, Policy and Practice 2011 1:1. 